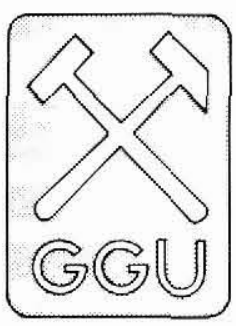

\title{
Ice conditions offshore West Greenland
}

\author{
Henrik Højmark Thomsen
}

An offshore West Greenland licensing round was formally approved by the Danish Minister of Energy on 26 March 1992, and announced in industry journals in the following months. To give interested companies an opportunity to familiarise themselves with the political framework, licensing terms, geology of the licensing area and general working conditions in Greenland, presentations were held in Europe and North America (Christiansen et al., this report). In addition GGU prepared a special information package 'Offshore West Greenland - Exploration Information 1992' for the licensing round. One of the enclosures in this package is a brief review of ice conditions offshore West Greenland with particular reference to the licensing area (Thomsen, 1992; Fig. 1). The licensing round failed to attract any applications, but ice conditions offshore West Greenland remain of prime interest to any group planning geophysical or environmental studies in the area. For this reason a summary of the report enclosed in the information package is given here.

\section{Ice conditions}

The ice that occurs in Greenland waters can be broadly classified into the following main types: (1) 'storis', mainly multi-year pack ice; (2) 'vestis', mainly first-year pack ice; (3) fast ice, coastal first-year ice; (4) icebergs from glaciers. All four types of ice are encountered to a varying degree in the licensing area offshore West Greenland.

Storis. Storis (Danish word meaning 'great ice') is a highly complex conglomerate of pack ice. It is carried by the East Greenland current southwards along the coast of East Greenland to Kap Farvel, the southernmost extension of Greenland, and then northwards along the coast of West Greenland with the West Greenland current (Fig. 1). A large part of this pack ice is thick multi-year ice formed in the Arctic Ocean through several winters and transported into the Greenland Sea through the Fram Strait. A comprehensive review of the sea ice conditions in the Greenland Sea is found in Wadhams (1981).

The Danish Hydraulic Institute (DHI, 1991) de- scribes the maximum thickness of this pack ice as being about 4 metres in the Fram Strait, decreasing to about 2 metres at Kap Farvel. However, strongly consolidated pressure ridges are common. Rough guesses of the maximum keel draft of pressure ridges are 30 metres in the Fram Strait, decreasing to 10 metres at Kap Farvel. Average sail to keel draft ratios of $1: 3$ to $1: 5$ are suggested by DHI (1991):

The amount of storis along the south-west coast of Greenland varies seasonally and from year to year (Nielsen et al., 1978). The edge of this pack ice normally passes Kap Farvel in January or February, but this can vary by several months from year to year. Between 1900

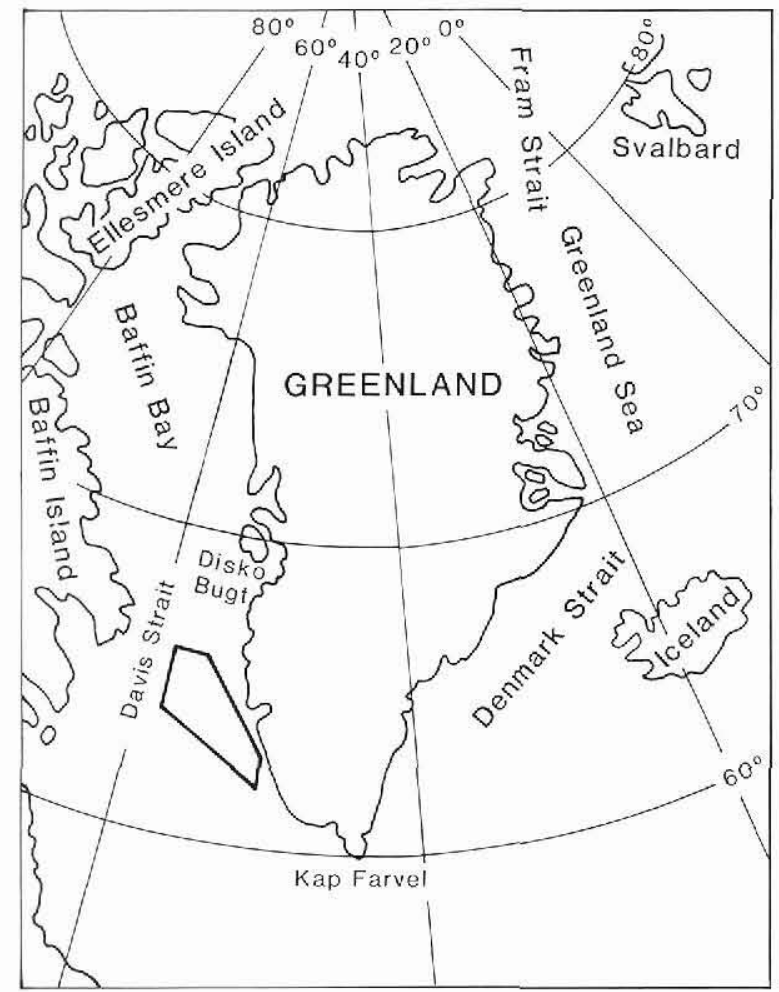

Fig. 1. Map showing place names mentioned in text, with the area of the sea ice statistical survey shown by black frame. The survey area is a simplified outline of the licensing area offshore West Greenland. 
and 1976 the earliest date of passage of the pack ice was 10 October 1921, and the latest date was 20 May 1947 (Nielsen et al., 1978). An early passage of pack ice at Kap Farvel does not necessarily mean there will be more storis on the south-west coast of Greenland. The pack ice often passes Kap Farvel in portions, with the main ice mass sometimes appearing much later than the time when the first storis was seen.

Vestis. Vestis (Danish word meaning 'west ice') is the ice formed along Ellesmere Island and Baffin Island and carried by currents out into central Baffin Bay and Davis Strait (Fig. 1). By far the largest part of this pack ice is first-year ice, but multi-year ice originating from the North American archipelago and the Arctic Ocean may occur in smaller amounts. During September, the amount of ice in Baffin Bay and Davis Strait is at its lowest level. In the following months this amount increases until it reaches its maximum extent usually in March, after which the amount decreases.

Because vestis is formed in the course of only one winter and farther south than the East Greenland pack ice, it is not as thick as the latter. As very few measurements of the thickness of the vestis have been made, ice thickness figures have been estimated on the basis of calculations of the growth of first-year ice (Buch, 1981). The calculations show that a maximum first-year ice thickness of about $1.4 \mathrm{~m}$ can be expected offshore in Baffin Bay. In Davis Strait the maximum first-year ice thickness is estimated to be about $1.4 \mathrm{~m}$ in the western part and $1.1 \mathrm{~m}$ to $1.2 \mathrm{~m}$ in the eastern part. In the winter and spring of 1976 the vestis had one of its largest extensions in historical time. In May 1976, ice floes with a thickness ranging from $0.7 \mathrm{~m}$ to $1.5 \mathrm{~m}$ were recorded in positions between $55^{\circ} \mathrm{W}$ to $56^{\circ} \mathrm{W}$ and $65^{\circ} \mathrm{N}$ to $66^{\circ} \mathrm{N}$ (Nielsen et al., 1978).

Formation of pressure ridges is common, but the pressure ridges in West Greenland are generally smaller than in East Greenland and less consolidated because many are first-year features (DHI, 1991). On the basis of a survey on the sea ice surface in Baffin Bay in 1977-1978 it was found that there is a great spread in the frequencies of ice ridges, but the mean height of the ridges is about $1 \mathrm{~m}$ (Buch, 1981). However, there is a tendency towards an increasing frequency of ridges from the beginning of the ice season in early winter to the high ice season in early spring.

Fast ice. Fast ice is the land-fast ice that forms during the winter in the fjords and along the coast. The thickness of this ice in West Greenland is small, as it is formed during only one winter. Measurements of the fast ice thickness in southern West Greenland give figures of about 0.7 metres (DHI, 1991). Because of the

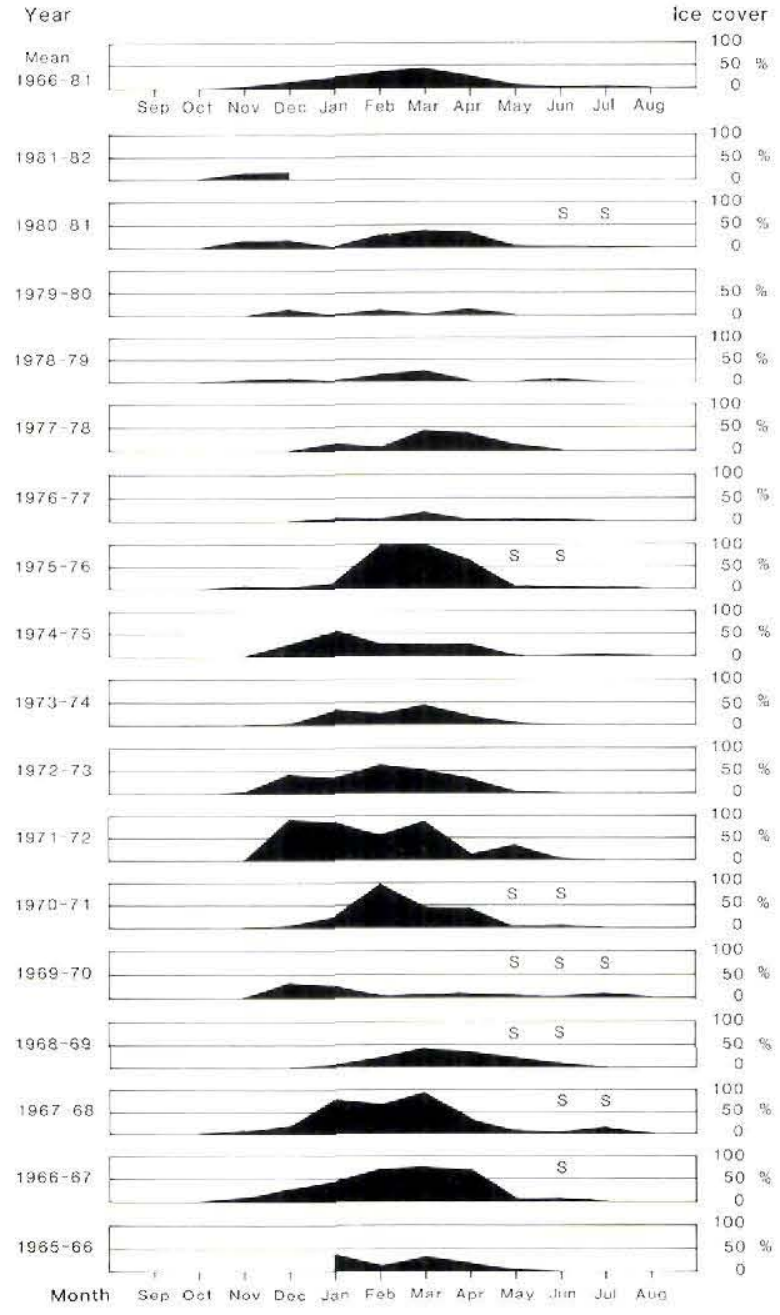

Fig. 2. Ice cover in the survey area offshore West Greenland on a monthly basis for the period 1966-1981. The survey area is shown in Fig. 1. The given ice cover is the percentage of the survey area covered with ice of any concentration. Months marked with $S$ are months where the largest part of the ice cover is storis. The uppermost graph shows the mean seasonal ice cover for the period 1966-1981.

frequent storms and the considerable tidal range, fast ice does not become established along the outer coast unless storis or vestis provides protection and reduces the water temperature. Inside the fjords and among the skerries, fast ice will form even without the protection of storis or vestis.

Glacier ice. Icebergs are formed by calving where glaciers reach sea level, and hence they can be encountered in Greenland waters at all times of the year. Most icebergs come from glaciers draining from the Greenland Inland Ice. The most productive glaciers are lo- 
cated on the southern east coast of Greenland, in central West Greenland around Disko Bugt and farther north along the west coast. The discharge of icebergs from the fjords of Greenland is prevented during winter by coastal fast ice, and the largest concentrations of transient icebergs are therefore found after the fast ice has broken up. The fact that icebergs are encountered in Greenland waters at all times of the year is due to the irregular current and wind-induced movement of the iccbergs, with frequent groundings, and the fact that large icebergs can survive for many years in the cold waters around Greenland.

Icebergs were counted and tracked offshore West Greenland in the period 1975-78 (GTO. 1979a, b; DHI, 1991). In general, icebergs originating from East Greenland drift south along the east coast with the East Greenland current and most of them continue to drift around the southern tip of Greenland at Kap Farvel and then northwards along the coast of West Greenland. Icebergs from Disko Bugt either drift north towards Baffin Bay or south towards Davis Strait. Icebergs originating farther north along the west coast probably follow the general large-scale anticlockwise current circulation in Baffin Bay and join the southwards-flowing Labrador current along the east coast of Canada.

Detailed statistics of iceberg counts offshore West Greenland for the months May to October 1975-1978 are given by GTO $(1979 \mathrm{a}, \mathrm{b})$. It appears that minimum iceberg densities are found between latitudes $65^{\circ} \mathrm{N}$ and $66^{\circ} \mathrm{N}$. From this minimum area the iceberg density increases both towards the north and south.

The mass and draft of icebergs were also calculated or measured during the period 1975-1978 (GTO, 1979a. b). The results show that the largest icebergs are most frequently found in the area south of latitude $64^{\circ} \mathrm{N}$ and the area north of latitude $66^{\circ} \mathrm{N}$.

\section{Sea ice in the licensing area offshore West Greenland}

Statistics for sea ice conditions have been compiled for a survey area offshore West Greenland (Fig. 2). where the survey area is a simplified outline of the new licensing area (Fig. 1).

These statistics are based on monthly charts of the sea ice conditions in Greenland waters compiled by the Danish Meterological Institute (DMI, 1966-1981). The charts cover the period 1966-1981 and depict the ice conditions around the end of each month in question.

Figure 2 shows the percentage of the survey area covered by ice of any concentration on a monthly basis for the period 1966 to 1981. Furthermore a mean
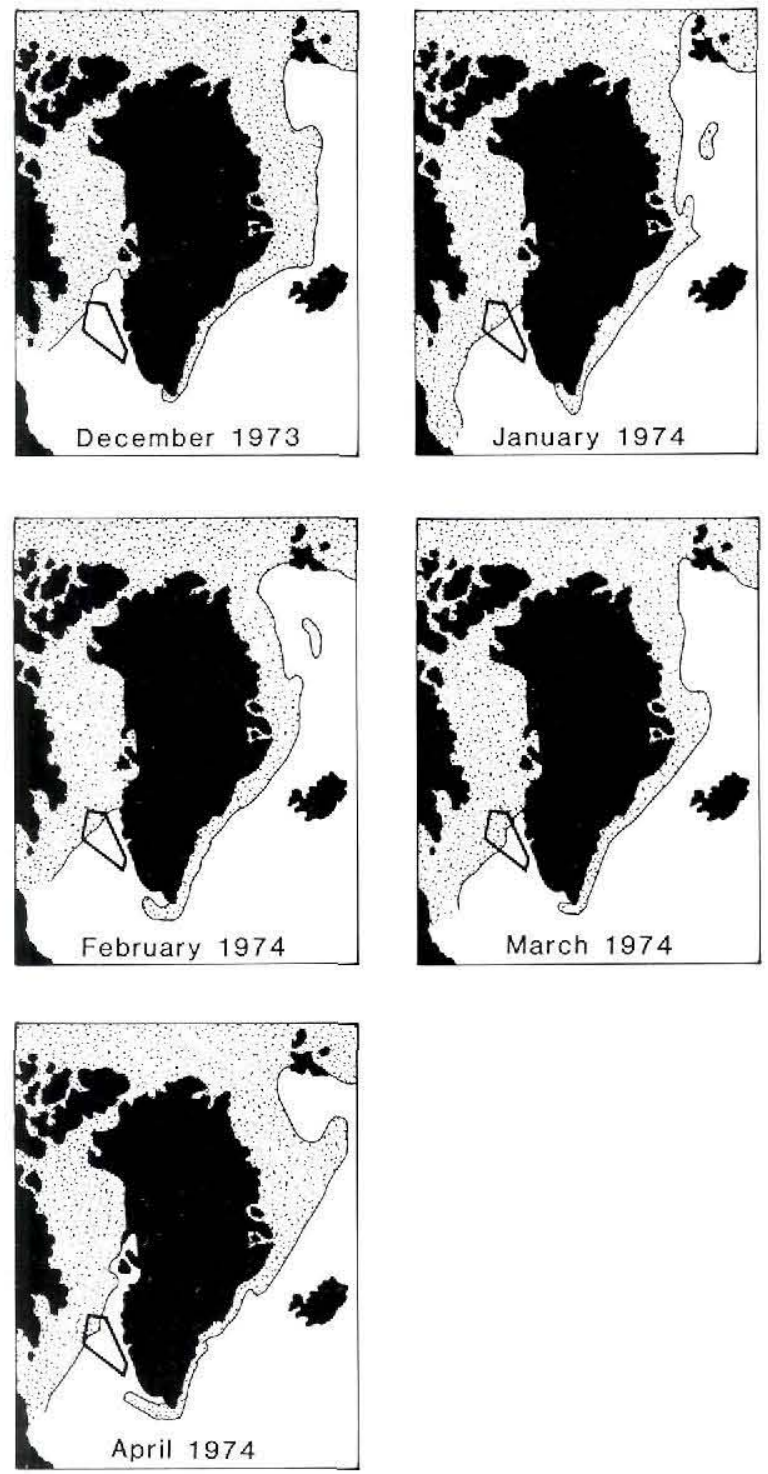

Fig. 3. Illustration of a typical ice cover development. Ice edge movement over the survey area is shown for the period December 1973 to April 1974. The ice cover in 1973-1974 represents ice conditions close to the mean seasonal ice cover 1966-1981. Source: DMI (1966-1981).

monthly ice cover has been calculated for the whole period 1966-1981. As a mean, ice starts building up in the survey area in November. In the following months, the ice cover increases until it reaches its maximum extent in March, after which the ice cover decreases and the entire area is ice-free at the end of August. The maximum mean ice cover for the period 1966-1981 was $48 \%$ in March and the mean ice cover was normally less than $10 \%$ in the period May to August. However, there 
is a large year-to-year variation from this pattern. In nine out of the 16 years an ice cover first started to build up at the beginning of December or later, and the area was ice-free again in late July or earlier in 11 out of the 16 years.

The pattern of ice advance and decay in the survey area is similar from year to year. This is illustrated by an example of the ice cover development from December 1973 to April 1974, when the ice cover development was close to the mean seasonal development for the whole period 1966-1981 (Fig. 3). The ice build-up starts with vestis advancing over the area from the north-west. A NE-SW trending edge of vestis then advances over the area from the north-west to the south-east. The ice decay follows a similar but reverse pattern.

In heavy ice years the whole or large parts of the survey area will be covered with ice, and vestis will join up with the fast ice along the West Greenland coast. This was the case in 1976 when the whole survey area was covered with ice at the end of February and in March (Fig. 2). In 1967, 1968, 1971 and 1972, which were also heavy ice years, the maximum ice cover in the survey area varied between $79 \%$ and $95 \%$.

In these years only the south-easternmost part of the survey area was ice-free. In 1972 the ice build-up was preceded by a rapid ice advance at the end of December 1971, and the ice cover remained high until the end of March 1972. In 1971 the large ice coverage only existed for a short part of the winter with an ice cover mainly below $50 \%$.

In light ice years, e.g. 1970, 1977, 1979 and 1980, the maximum ice cover in the survey area varied between $16 \%$ and $27 \%$, leaving only the north-westernmost corner of the area covered with ice.

In some years storis from East Greenland advances into the survey area from the south-east and covers a narrow part of the area. This advance of storis normally takes place during February or March and the ice stays in the area until the end of June or July. This is illustrated with an example of the ice cover development from the period March 1970 to July 1970 when storis was present in the survey area for a long period in the spring and early summer (Fig. 4). From the statistics it can be seen that there were several years when ice remained in the area until late June or July; the remaining ice cover is storis (months marked with $S$ on Fig. 2). In these years the last ice only covers a narrow part of the survey area in the south-east.

Further information about the ice conditions in the licensing area can be found in a comprehensive study of the variation in vestis by the Danish Meteorological Institute (DMI, 1976). This study describes the position of vestis for each half degree of latitude each week of
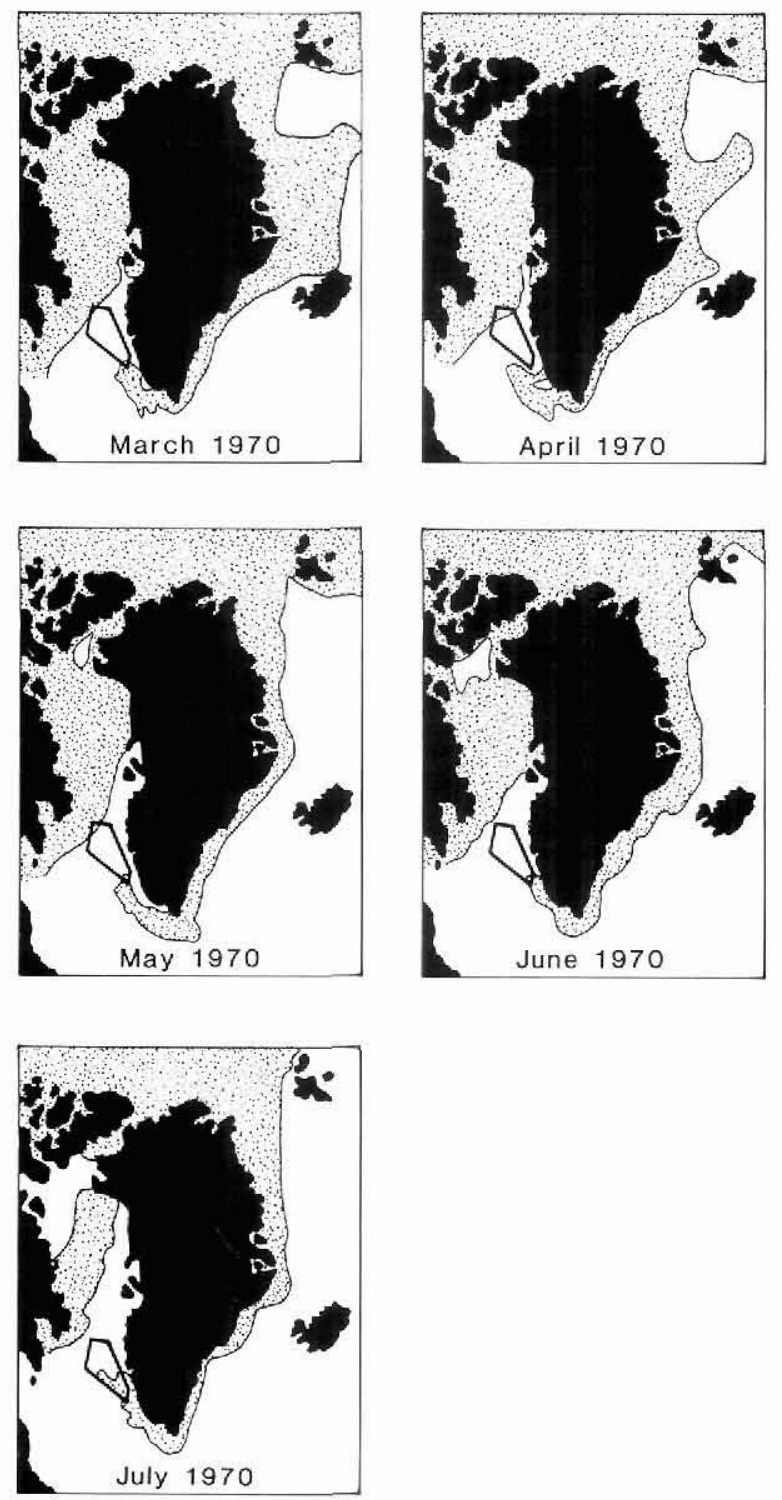

Fig. 4. Illustration of the late arrival and presence of storis in the survey area. Ice edge movement over the survey area is shown for the period March 1970 to July 1970. The year 1970 also represents a year with a generally small ice cover (cf. Fig. 2). Source: DMI (1966-1981).

the year from 1959 to 1974 between latitudes $62^{\circ} \mathrm{N}$ and $70^{\circ} \mathrm{N}$.

\section{References}

Buch, D. 1981: Regional climate and oceanography of Baffin Bay north of $60^{\circ} \mathrm{N}$ to Lancaster Sound. In Peterson, N. M. (ed.) The question of sound from icebreaker operations. Proc. Workshop Toronto, Canada, 23-24 Feb. 1981. Arctic Pilot Project. Petro-Canada, 20-71. 
DHI, 1991: Technology assessment for arctic offshore oil production; applied to Greenland. Report by Arctic Consultant Group A/S \& Danish Hydraulic Institute, 303 pp.

DMI, 1966-1981: The ice conditions in the Greenland waters, 1966-1981. Annual publications 1966-1981. Danish Meteorological Institute, Copenhagen, Denmark.

DMI, 1976: West ice investigations. Part I. West ice histograms 1959-1974. Danish Meteorological Institute, Nautical Department, $204 \mathrm{pp}$.

GTO, 1979a: Environmental conditions offshore West Greenland Vol. I. Summary, Data bank contents. Report from Danish Hydraulic Institute under contract for Greenland Technical Organization, 101 pp.

GTO, 1979b: Environmental conditions offshore West Greenland Vol. IV. Icebergs. Report from Danish Hydraulic In- stitute under contract for Greenland Technical Organization, $158 \mathrm{pp}$.

Nielsen, A. H., Dietrich, J. \& Fabricius, J. S. 1978: Environmental conditions on the continental shelf off West Greenland. J. Petrol. Techn. 30, 1381-1391.

Thomsen, H. H. 1992: Ice conditions offshore West Greenland - an introduction (enclosure 5). In Offshore West Greenland - Exploration Information 1992. Unpubl. intern. GGU rep., $11 \mathrm{pp}$.

Wadhams, P. 1981: The ice cover in the Greenland and Norwegian Seas. Rev. Geophys. Space Phys. 19, 345-393.

H. H. T., Geological Survey of Greenland, Copenhagen.

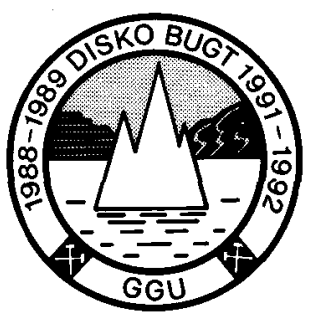

\title{
Disko Bugt Project 1992, West Greenland
}

\author{
Flemming G. Christiansen
}

One of GGU's major field activities in 1992 took place in July and August in the Disko-Nuussuaq-Svartenhuk Halvø area of central West Greenland. This was the fourth and final year of field studies under the 'Disko Bugt Project', carried out from 1988-1992 with one summer's break in 1990.

The Disko Bugt Project includes a large number of activities, essentially within two very different geological provinces: the Archaean-Proterozoic basement and supracrustal province, and the onshore part of the Cretaceous-Tertiary sedimentary and volcanic basin. The Precambrian basement is mainly exposed towards the east, and the sediments and volcanic rocks mainly towards the west (Fig. 1).

The main aims of the Disko Bugt Project are to assess the resource potential of the region with respect to minerals (mainly in the Precambrian supracrustal rocks) and hydrocarbons (in the neighbouring offshore basins).

During the previous three field seasons the base camp was situated at the abandoned settlement Ataa (Fig. 1), and work was concentrated on the basement and supracrustal rocks on Arveprinsen Ejland and the areas towards the east and north-east (see Kalsbeek, 1989, 1990; Kalsbeek \& Christiansen, 1992). This work was completed in 1991 with the exception of studies of the mineral potential of the Lower Proterozoic Karrat Group (Thomassen, 1992). In 1992 the headquarters of the expedition was the town of Uummannaq and field work focused on the sedimentary and volcanic succession on Nuussuaq and Svartenhuk Halvø and included a shallow core drilling campaign. Studies of the volcanic rocks are a continuation of a long-term research programme whereas the sedimentary basin studies were more extensive in 1992 than in previous years (see overview in Christiansen et al., 1992 and Kalsbeek \& Christiansen, 1992).

The Disko Bugt Project is being carried out as a collaboration between GGU and scientists and students from a number of other institutions and universities. In 